\title{
Malignancy risk of hyperfunctioning thyroid nodules compared with non-toxic nodules: systematic review and a meta-analysis
}

Lorraine W. Lau ${ }^{1,2}$, Sana Ghaznavi ${ }^{1,2}$, Alexandra D. Frolkis ${ }^{1}$, Alexandra Stephenson ${ }^{3}$, Helen Lee Robertson ${ }^{4}$, Doreen M. Rabi ${ }^{2,5}$ and Ralf Paschke $e^{1,2,6^{*}}$ (i)

\begin{abstract}
Background: Hyperfunctioning or hot nodules are thought to be rarely malignant. As such, current guidelines recommend that hot nodules be excluded from further malignancy risk stratification. The objective of this systematic review and meta-analysis is to compare the malignancy risk in hot nodules and non-toxic nodules in observational studies.

Methods: Ovid MEDLINE Daily and Ovid MEDLINE, EMBASE, Scopus, and Web of Science databases were searched. Observational studies which met all of the following were included: (1) use thyroid scintigraphy for nodule assessment, (2) inclusion of both hyperfunctioning and non-functioning nodules based on scintigraphy, (3) available postoperative histopathologic nodule results, (4) published up to November 12, 2020 in either English or French. The following data was extracted: malignancy outcomes include malignancy rate, mapping of the carcinoma within the hot nodule, inclusion of microcarcinomas, and presence of gene mutations.

Results: Among the seven included studies, overall incidence of malignancy in all hot thyroid nodules ranged from 5 to $100 \%$ in comparison with non-toxic nodules, $3.8-46 \%$. Odds of malignancy were also compared between hot and non-toxic thyroid nodules, separated into solitary nodules, multiple nodules and combination of the two. Pooled odds ratio (OR) of solitary thyroid nodules revealed a single hot nodule OR of 0.38 ( $95 \%$ confidence interval (CI) $0.25,0.59$ ), toxic multinodular goiter OR of 0.51 ( $95 \% \mathrm{Cl} 0.34,0.75)$, and a combined hot nodule OR of 0.45 (95\% $\mathrm{Cl}$ 0.31, 0.65). The odds of malignancy are reduced by $55 \%$ in hot nodules; however, the incidence was not zero.
\end{abstract}

Conclusions: Odds of malignancy of hot nodules is reduced compared with non-toxic nodules; however, the incidence of malignancy reported in hot nodules was higher than expected. These findings highlight the need for further studies into the malignancy risk of hot nodules.

Keywords: Thyroid nodules, Malignancy, Hot nodule, Thyrotoxicosis, Thyroid cancer

\footnotetext{
* Correspondence: ralf.paschke@ucalgary.ca

'Department of Medicine, Cumming School of Medicine, University of Calgary, Calgary, Canada

${ }^{2}$ Section of Endocrinology and Metabolism, Department of Medicine, Cumming School of Medicine, University of Calgary, Calgary, Canada

Full list of author information is available at the end of the article
}

(c) The Author(s). 2021 Open Access This article is licensed under a Creative Commons Attribution 4.0 International License, which permits use, sharing, adaptation, distribution and reproduction in any medium or format, as long as you give appropriate credit to the original author(s) and the source, provide a link to the Creative Commons licence, and indicate if changes were made. The images or other third party material in this article are included in the article's Creative Commons licence, unless indicated otherwise in a credit line to the material. If material is not included in the article's Creative Commons licence and your intended use is not permitted by statutory regulation or exceeds the permitted use, you will need to obtain permission directly from the copyright holder. To view a copy of this licence, visit http://creativecommons.org/licenses/by/4.0/. The Creative Commons Public Domain Dedication waiver (http://creativecommons.org/publicdomain/zero/1.0/) applies to the data made available in this article, unless otherwise stated in a credit line to the data. 


\section{Background}

Autonomously hyperfunctioning thyroid nodules represent approximately $5-10 \%$ of all thyroid nodules. These so-called "hot nodules" are defined by increased radiotracer uptake compared to surrounding thyroid parenchyma on scintigraphy. Hot nodules can exist as a single hot nodule or as toxic multi-nodular goiters (TMNG). The degree of autonomous hyperfunction in hot nodules is variable, and some hot nodules may not produce sufficient levels of thyroid hormones to suppress TSH levels at initial presentation [1-4]. Clinical care pathways for the management of thyroid nodules recommend measurement of serum thyrotropin (TSH) followed by scintigraphy in patients with the presence of thyroid nodules and subnormal TSH levels [5]. Scintigraphy use in patients with normal TSH levels has been questioned [2] and is more commonly utilized in Europe [4].

Compared to non-toxic nodules, hot nodules are traditionally believed to have an exceptionally low rate of malignancy. This has led to widely-adopted recommendations by several guideline groups not to perform fine needle aspiration biopsy on these lesions irrespective of their size [1-7]. However, recent studies have challenged the presumed low-risk of malignancy in hot nodules, suggesting that the incidence of cancer has been underestimated [6-10]. In 22 patients who underwent thyroid surgery irrespective of functional nodule status, Ashcraft and Van Herle reported a malignancy risk of $4 \%$ in hot nodules $[11,12]$. A recent study demonstrated higher than expected malignancy rates in hot nodules with an overall malignancy rate of $8.5 \%$ [13]. The reported malignancy rates of hot nodules ranges broadly from 0.34 to $44 \%$ among patients undergoing thyroid surgery $[14,15]$. In comparison, the reported malignancy rate of non-toxic nodules ranges from 8 to $16 \%[7,11-13,16,17]$.

Given the current recommendation against cytologic evaluation of hot nodules, and the widely variable malignancy rate reported in these lesions, there is a need to critically appraise the current literature in this area. Therefore, this systematic review aims to address the question: among those individuals undergoing thyroidectomy for benign indication, are hot nodules diagnosed by scintigraphy associated with a lower risk of thyroid malignancy compared with non-toxic thyroid nodules? Secondary objectives include comparison of malignancy risk in single compared with multiple hot nodules, assessment of reported carcinomas within compared to outside the hot nodule, association of hyperfunctioning on scintigraphy compared with biochemical hyperfunctioning (as determined by TSH levels) and its impact on malignancy, and the impact of inclusion of microcarcinomas on malignancy rates of hot nodules.

\section{Methods}

\section{Protocol and registration}

This systematic review was registered with a pre-published protocol on PROSPERO (CRD42019119204). Reporting was in accordance with the preferred reporting items for systematic review and meta-analyses (PRISMA) [18].

\section{Search strategy and databases}

Two investigators (LL \& RP) created a preliminary search strategy that was subsequently refined by a medical librarian (HLR). In brief, a search strategy aimed to include all articles from human studies published up to November 12,2020 that utilized scintigraphy to assess functional status of thyroid nodules and subsequently included histopathologic data on these nodules. Complete search terms are available in Supplemental Fig. 1. Citations were found by searching the following databases from the first date available to November 12, 2020: Epub Ahead of Print, InProcess \& Other Non-Indexed Citations, Ovid MEDLINE Daily and Ovid MEDLINE, EMBASE, Scopus, and Web of Science. Combinations of subject headings, keywords and synonyms used included all three key terms: 1) thyroid nodule, 2) hyperthyroidism, thyrotoxicosis, and hot nodule and 3) thyroid neoplasm, thyroid carcinoma, medullary carcinoma, follicular carcinoma, papillary carcinoma, and anaplastic carcinoma. The formalized search strategy is summarized in the Supplementary information.

\section{Study selection}

After duplicates were removed, two reviewers (LL \& AS) independently screened 1464 articles. Initial screen of the title \& abstract for full text assessment was determined based on mention of thyroid nodule functional status and inclusion of surgical pathology. An additional 5 articles were added from other sources. These sources include review of references in published reviews and included articles, and additional articles recommended by expert researchers and clinicians in the field. Case reports, review articles, and small series $(n \leq 10)$ studies were excluded. Studies that included nodules noted outside the thyroid gland were also excluded. Inclusion criteria included studies that used thyroid scintigraphy $\left({ }^{131} \mathrm{I} /{ }^{123} \mathrm{I}\right.$ or $\left.\mathrm{T}^{99 \mathrm{~m}}\right)$ for nodule assessment, inclusion of both hyperfunctioning and normo -/hypo-functioning nodules based on scintigraphy, available postoperative histopathologic nodule results, and no age restriction. The reviewers (LL \& AS) independently determined if studies met inclusion and exclusion criteria. Discrepancies were settled by a third reviewer (RP).

\section{Data extraction}

Among the articles that met inclusion and exclusion criteria for analysis, the data extracted is summarized in Supplemental Table 1. In brief, quantitative measures included sample size, gender distribution, number of hot 
nodules and non-hot nodules and distribution of thyroid carcinomas. Binary measures included clear description of the thyroid carcinoma within the nodule, inclusion of microcarcinomas, and presence of genetic mutations. Data management was performed with Microsoft Excel. Furthermore, incidence of malignancy was calculated for all hot nodules and non-toxic nodules.

\section{Data analysis}

Analyses were performed exploring the pooled odds ratio (OR) and 95\% confidence interval (CI) of malignancy in: 1) single hot thyroid nodules compared with non-toxic nodules based on scintigraphy; 2) toxic multinodular goiters containing a hot nodule compared with non-toxic multinodular goiters; and 3) all hot nodules. Heterogeneity across studies was determined using Cochran's Q and $I^{2}$ statistic [19]. Due to the presence of significant heterogeneity, Mantel-Haenszel-weighted DerSimonian and Laird random-effects model were utilized [20]. Meta-regressions were not performed due to limited sample size. All analyses were performed using Stata 14.2 with an alpha of 0.1 and Review Manager 5.3 (Version 5.3.5, The Cochrane Collaboration, Copenhagen, Denmark).

\section{Quality assessment}

The methodological assessment of included cohort studies was assessed by two independent reviewers (LL, RP) using the Newcastle-Ottawa Scale [21]. The role of this tool is to assess for patient selection bias, and for comparability of study groups and study outcomes.

\section{Results}

Search results

Our search results are summarized in Fig. 1. Among 2487 citations identified for review, there were 1644 remaining after removal of duplicates. Upon review of title and abstract, 83 full text articles were reviewed. Based on our exclusion criteria, 76 articles were excluded (reasons summarized in Supplementary Tables 2 and 3) with 7 studies included for qualitative and quantitative synthesis.

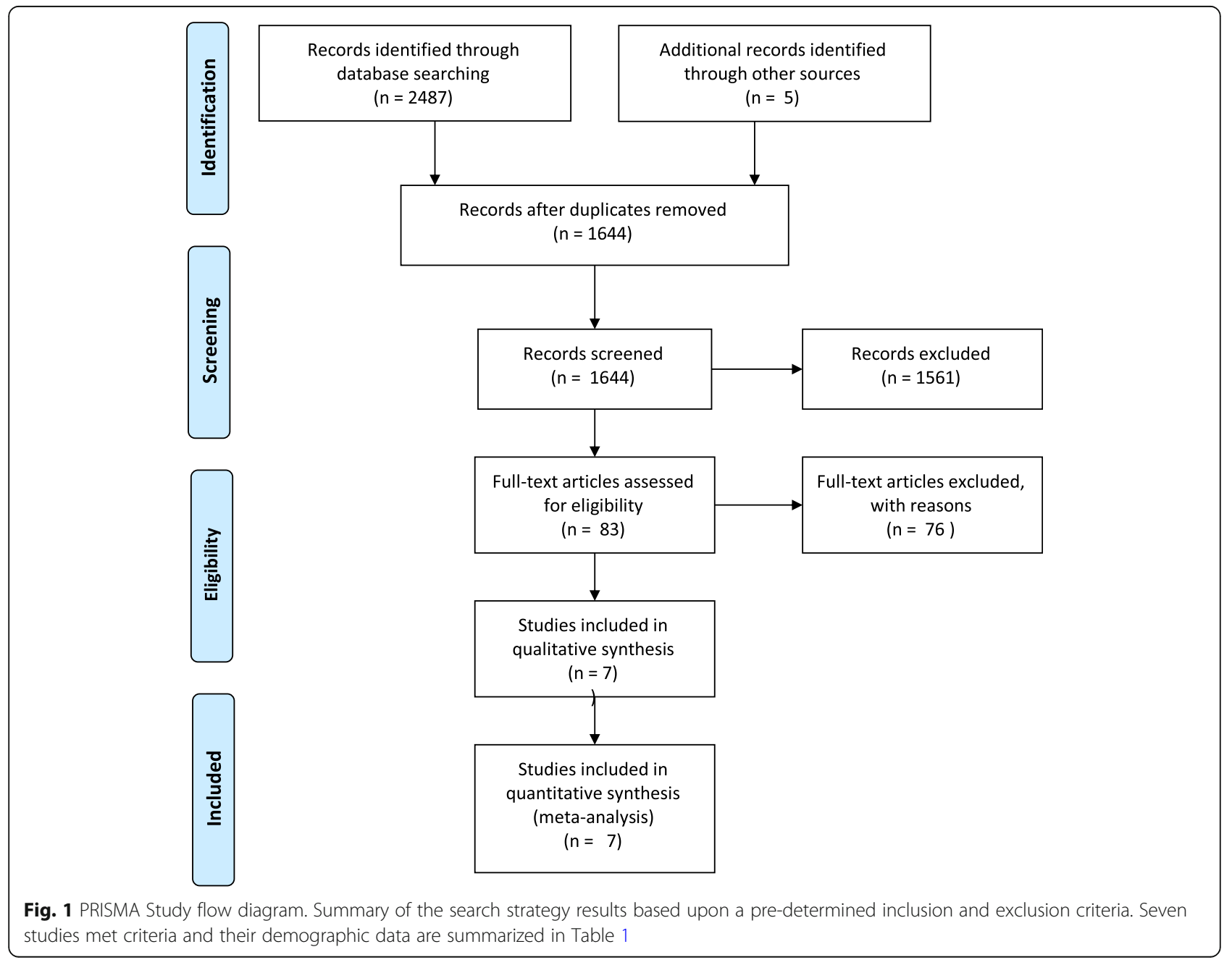




\section{Characteristics of included studies}

A summary of the 7 observational studies included in our synthesis is presented in Table 1 [9, 22-27]. Publication dates ranged from 1994 to 2019. Studies originated predominantly from Europe, with 2 of 7 from Italy and 2 of 7 from Turkey. Total number of thyroid nodules across all studies was 7726, which ranged from 120 to 2870 nodules per study. Mean age ranged from 11.5 to 54 years old. Overall, most studies were surgical cohort studies that retrospectively examined predictors of malignancy. Thyroid carcinomas were diagnosed by fine needle aspiration biopsy (FNAB) and/or surgical histology. Scintigraphy was conducted with $\mathrm{Tc}^{99 \mathrm{~m}}$ in 5 of 7 studies. In these five studies, scintigraphy was routinely performed in all the patient cohorts. Microcarcinomas were reported in 5 of 7 studies. Microcarcinomas comprised between 9.5 to $100 \%$ of the carcinomas reported in the studies. Among the 7 studies, only two study provided clear localization of the thyroid carcinoma within the hot nodule as these pediatric patients only had one nodule $[23,27]$. In the other 4 studies, it is unclear if the carcinoma was confirmed within the hot nodule or in adjacent thyroid tissue.

TSH level was measured in all studies. However, only two studies reported the TSH levels and correlated these levels with scintigraphy results $[9,23]$. The three other studies did not directly report TSH levels for hot nodules [22, 24-27].

\section{Malignancy rate in hot nodules}

Hot nodules were differentiated into single hot nodules and TMNG. Similarly, non-toxic nodules were differentiated into single non-toxic nodules (NTN) and nontoxic multinodular goiters (MNG). Study outcomes for the odds ratio of single hot nodules versus single NTN are shown in Fig. 2. Pooled odds ratio in 5 studies involving 6778 nodules demonstrated a lower odd of malignancy in single hot nodules $(\mathrm{OR}=0.38 ; 95 \% \mathrm{CI} 0.25$, $\left.0.59 ; \mathrm{I}^{2}=<0.0002\right)$ compared to single NTN. Mon et al. represented a distinct outlier with an OR of $5.50(95 \%$ CI $0.23,128.97$ ) [9]. Malignancy rates are reported malignancy per rates per nodule. Both Baser et al. and Tam et al. were excluded as it was unclear whether nodules were solitary or MNG [22, 27].

The pooled odds ratio of 4 studies involving 6658 individuals demonstrated a lower odd of malignancy in TMNG compared to non-toxic MNG (OR $=0.51 ; 95 \%$ CI $0.34,0.75 ; I^{2}=48.3 \%$ ). These outcomes are summarized in Fig. 3. Mon et al. was a clear outlier in comparison with the three other studies with an OR of 23 (95\% $\mathrm{CI}=0.61,862.86$ ) [9]. Corrias et al. was excluded from this analysis as MNGs were absent in their study [23].

The overall pooled OR for all hot nodules, including both single and multiple nodules, was lower in comparison to all non-hot nodules $(\mathrm{OR}=0.45 ; 95 \% \mathrm{CI}$ $\left.0.31,0.65 ; I^{2}=57 \%\right)$. These outcomes are summarized in Fig. 4.

Incidence of malignancy was calculated for all nodules and is summarized in Table 2. Among the 7 studies, the overall incidence of malignancy in all hot nodules ranged from 5 to $100 \%$ in comparison with non-toxic nodules, ranging from $3.8-46 \%$. The FNA cytology and surgical histology results are also summarized in Table 2.

\section{Assessment of bias and quality of evidence}

Risk of bias was assessed using the Newcastle-Ottawa assessment scale for cohort studies, which evaluated the quality of the evidence based on selection, comparability, and outcome (Table 3) [21]. Only one study was assessed as low risk with 6 stars; however, this study evaluated only pediatric patients [23]. All other studies were assessed as having high risk of bias as they were all surgical cohorts without a non-surgical (ie. medically managed) cohort for comparison, thus awarded 5 stars or less. Furthermore, Mon et al. was assessed with high risk of bias in comparability as this study selected specifically for patients with TSH receptor mutation without a mutation negative study control. Follow up duration and adequacy were not applicable to the assessment.

\section{Post-hoc assessment of malignancy outcomes in studies reporting hot nodules only}

Given the higher than expected incidence of malignancy in the included studies, studies that were excluded due to lack of non-toxic nodules were re-examined. Specifically, the incidence of malignancy in hot nodules was evaluated in single hot nodules and TMNG. These findings are reported in Supplementary Table 4. Quantitative assessment was not performed as the comparability of the studies was not appropriate. Incidence of malignancy ranged from 0 to $44 \%$ in single hot nodules, $0-26 \%$ in TMNG, and $0-29 \%$ in all hot nodules (single hot nodules and TMNG).

Furthermore, post hoc analysis of odds of malignancy in only adult patients without a prior knowledge of TSHR mutations is summarized in Supplemental Fig. 1. Pooled ORs of all hot nodules was lower than all nontoxic nodules (ORs $0.43,95 \%$ CI $0.32,0.58, I^{2}=46 \%$ ).

\section{Case reports identified through the search strategy}

Based on our search strategy, 62 case reports of thyroid carcinoma within a hot nodule were identified with publication dates from 1972 to present. Demographic information was extracted from these case reports and are seen in Table 4. Patient age varied from 2 months to 74 years of age. Most hot nodules were single hot nodules, though some TMNGs were also included. Papillary thyroid carcinomas (PTCs) and follicular thyroid 


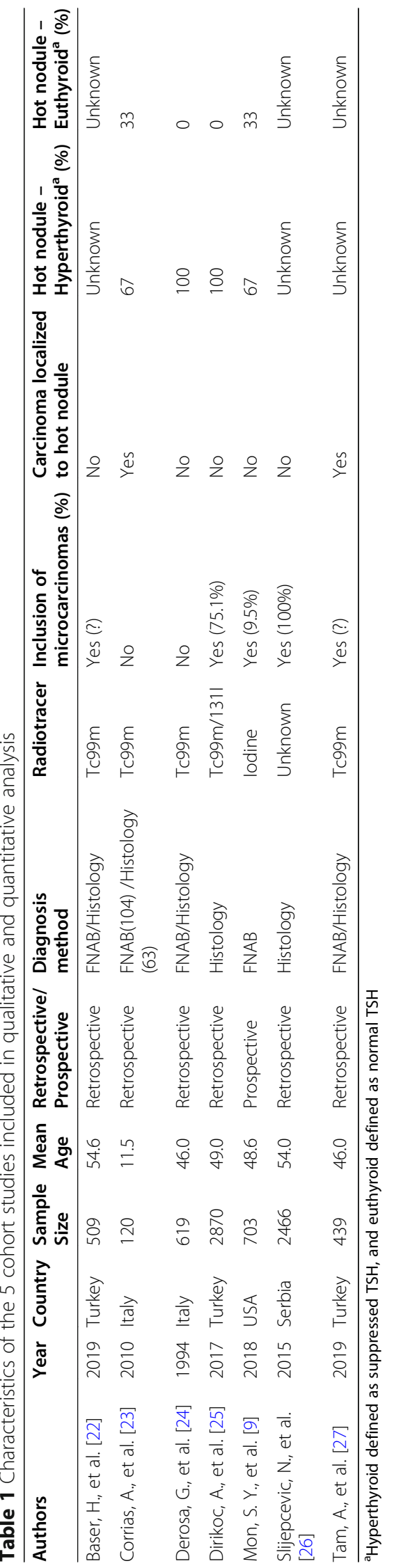




\begin{tabular}{|c|c|c|c|c|c|c|c|c|c|}
\hline Study or Subgroup & $\begin{array}{c}\text { Toxi } \\
\text { Events }\end{array}$ & $\begin{array}{l}\text { c } \\
\text { Total } \\
\end{array}$ & $\begin{array}{l}\text { Non-to } \\
\text { Events }\end{array}$ & $\begin{array}{l}\text { oxic } \\
\text { Total }\end{array}$ & Weight & $\begin{array}{l}\text { Odds Ratio } \\
\text { M-H, Random, } 95 \% \mathrm{Cl}\end{array}$ & $\begin{array}{r}\text { Odds } \\
M-H, \text { Ranc } \\
\end{array}$ & $\begin{array}{l}\text { Ratio } \\
\text { om, } 95 \% \mathrm{Cl}\end{array}$ & \\
\hline Corrias et al 2010 & 2 & 10 & 10 & 46 & $6.2 \%$ & $0.90[0.16,4.93]$ & & & \\
\hline Derosa et al 1994 & 3 & 62 & 33 & 255 & $12.2 \%$ & $0.34[0.10,1.15]$ & & & \\
\hline Dirikoc et al 2017 & 14 & 59 & 121 & 262 & $43.0 \%$ & $0.36[0.19,0.69]$ & $\longrightarrow$ & & \\
\hline Mon et al 2018 & 1 & 3 & 1 & 12 & $1.8 \%$ & $5.50[0.23,128.97]$ & & & \\
\hline Slijepcevic et al 2015 & 9 & 136 & 142 & 875 & $36.8 \%$ & $0.37[0.18,0.74]$ & & & \\
\hline Total $(95 \% \mathrm{Cl})$ & & 270 & & 1450 & $100.0 \%$ & $0.40[0.26,0.61]$ & & & \\
\hline \multirow{2}{*}{\multicolumn{7}{|c|}{$\begin{array}{l}\text { Total events } \\
\text { Heterogeneity: } \text { Tau }^{2}=0.00 ; \mathrm{Chi}^{2}=3.75, \mathrm{df}=4(\mathrm{P}=0.44) ; \mathrm{I}^{2}=0 \% \\
\text { Test for overall effect: } Z=4.22(\mathrm{P}<0.0001)\end{array}$}} & & & \\
\hline & & & & & & & $\begin{array}{c}0.1 \\
0.1 \\
\text { creased in non-toxic }\end{array}$ & increased $i$ & $\begin{array}{l}10 \\
\text { hot nodules }\end{array}$ \\
\hline
\end{tabular}

Fig. 2 Pooled odd ratios for malignancy risk of single hot thyroid nodules compared with single non-toxic nodules based on scintigraphy

carcinomas (FTCs) were the most commonly reported malignancies. However, follicular variant of papillary thyroid carcinomas (fvPTC), Hurthle cell, anaplastic (with a concomitant hot nodule) and medullary thyroid carcinomas (described as a cold area of the $\mathrm{HN}$ ) were also identified [28, 29].

Among these 62 case reports, only two (4\%) reported microcarcinomas within the hot nodules [30, 31]. In all 9 pediatric studies, there was sufficient evidence to support the presence of the thyroid carcinoma within the hot nodule [31-39]. In the 53 adult studies, $49 \%$ of studies had sufficient evidence to demonstrate thyroid carcinoma presence within the hot nodule $[8,29,35,40-63]$.

\section{Discussion}

This systematic review and meta-analysis of observational studies comparing the malignancy rate of hot nodules compared with non-toxic thyroid nodules demonstrated a reduced malignancy rate in hot nodules; however, the rate was not as low as previously expected. Therefore, the findings of this review prompt us to question the widely adopted recommendation to avoid cytologic evaluation of hot nodules, based on the belief that hot nodules harbour a significantly lower malignancy rate than non-toxic nodules. Our findings cannot definitively support or refute this recommendation; however, this review gives us important insight into the methodological and evidence limitations in this area of the literature, including the need for meticulous cytologichistologic and imaging correlation of nodules, and the need to explicitly report malignancy rates with and without inclusion of incidental papillary microcarcinomas. Each of these issues will be discussed in detail below.

\section{Location of the thyroid carcinoma within the hot nodule}

A major challenge in the assessment of thyroid malignancy, particularly in multinodular goiters, is the location of the malignancy. It is not uncommon for a malignant nodule to co-exist with a benign nodule within the same thyroid lobe. This challenge can also be applied to hot nodules. Schroder and Marthaler evaluated 63 publications describing the presence of hot nodules with concurrent follicular or papillary thyroid cancer [64]. Out of the 63 publications, only 10 provided unequivocal confirmation of the carcinoma within the hot nodules, whereas in the other studies, it was uncertain whether the malignancy was found within the hot nodule or an adjacent non-toxic nodule. Interestingly, this study together with Pazaitou-Panaylotou et al described increased mortality in patients with carcinomas detected within the hot nodule $[64,65]$.

The identification of the carcinoma within the hot nodule can be technically difficult and requires close interdisciplinary collaboration. Localisation of the thyroid carcinoma in a specific nodule is particularly difficult in multi-nodular thyroid glands. However, accurate cytologic-histologic correlation of carcinomas is critical to understanding the true malignant potential of hot nodules [65]. Among the five studies included in this systematic review, Corrias et al identified the location of

\begin{tabular}{|c|c|c|c|c|c|c|c|c|c|}
\hline Study or Subgroup & \multicolumn{2}{|c|}{ Toxic } & \multicolumn{2}{|c|}{ Non-toxic } & Weight & \multirow{2}{*}{$\begin{array}{c}\begin{array}{c}\text { Odds Ratio } \\
\text { M-H, Random, 95\% Cl }\end{array} \\
0.35[0.13,0.95]\end{array}$} & \multicolumn{3}{|c|}{$\begin{array}{c}\text { Odds Ratio } \\
\text { M-H, Random, } 95 \% \mathrm{Cl}\end{array}$} \\
\hline Derosa et al 1994 & 5 & 81 & 23 & 144 & $12.0 \%$ & & -1 & & \\
\hline Dirikoc et al 2017 & 90 & 362 & 688 & 1646 & $48.1 \%$ & $0.46[0.36,0.60]$ & 7 & & \\
\hline Mon et al 2018 & 1 & 1 & 1 & 12 & $1.1 \%$ & $23.00[0.61,862.86]$ & 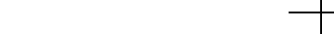 & & \\
\hline Slijepcevic et al 2015 & 38 & 278 & 187 & 875 & $38.7 \%$ & $0.58[0.40,0.85]$ & - & & \\
\hline Total $(95 \% \mathrm{Cl})$ & & 722 & & 2677 & $100.0 \%$ & $0.51[0.34,0.75]$ & & & \\
\hline Total events & 134 & & 899 & & & & & & \\
\hline $\begin{array}{l}\text { Heterogeneity: } \operatorname{Tau}^{2}= \\
\text { Test for overall effect: }\end{array}$ & $\begin{array}{l}0.07 ; \mathrm{Chi} \\
\mathrm{Z}=3.38\end{array}$ & $\begin{array}{l}P^{2}=5.8 \\
(P=0 .\end{array}$ & $\begin{array}{l}30, \mathrm{df}=3 \\
.0007)\end{array}$ & $3(P=0$ & $.12) ; I^{2}=$ & $=48 \%$ & $0.01 \quad 0.1{ }^{0}{ }^{1}$ Favours [experimental] & $\begin{array}{c}10 \\
\text { Favours [control] }\end{array}$ & 100 \\
\hline
\end{tabular}


Table 2 Reported incidence of malignancy in all nodules including hot nodules and non-toxic nodules

\begin{tabular}{|c|c|c|c|c|c|c|c|c|}
\hline Authors & $\begin{array}{l}\text { Overall } \\
\text { incidence of } \\
\text { malignancy (\%) }\end{array}$ & $\begin{array}{l}\text { Overall } \\
\text { proportion of } \\
\text { hot nodules (\%) }\end{array}$ & $\begin{array}{l}\text { Incidence of } \\
\text { malignancy in } \\
\text { single hot } \\
\text { nodules (\%) }\end{array}$ & $\begin{array}{l}\text { Incidence of } \\
\text { malignancy } \\
\text { in TMNG (\%) }\end{array}$ & $\begin{array}{l}\text { Incidence of } \\
\text { malignancy } \\
\text { in NTN (\%) }\end{array}$ & $\begin{array}{l}\text { Incidence of } \\
\text { malignancy } \\
\text { in MNG (\%) }\end{array}$ & $\begin{array}{l}\text { FNA Biopsy } \\
\text { results }\end{array}$ & $\begin{array}{l}\text { Malignant } \\
\text { Surgical } \\
\text { Histology }\end{array}$ \\
\hline $\begin{array}{l}\text { Baser, H., et al. } \\
\text { (2019) [22] }\end{array}$ & 5 & 73 & $\mathrm{~N} / \mathrm{A}$ & N/A & 3.8 & 6.6 & $\begin{array}{l}80- \\
\text { Nondiagnostic } \\
259-\text { Benign } \\
17 \text { - AUS/ } \\
\text { FLUS } \\
2 \text { - FN/SFN } \\
2 \text { - SM } \\
4 \text { - Malignant }\end{array}$ & $\begin{array}{l}8-\text { PTC } \\
2-\text { FTC } \\
3 \text { - TTUMP } \\
1-\text { UTC }\end{array}$ \\
\hline $\begin{array}{l}\text { Corrias, A., } \\
\text { et al. (2010) } \\
{[23]}\end{array}$ & 30 & 16 & 11 & 6 & 22 & 16 & 3 suspicious & $\begin{array}{l}1 \text { - PTC (All } 3 \\
\text { suspicious FNAB } \\
\text { were benign) }\end{array}$ \\
\hline $\begin{array}{l}\text { Derosa, G., } \\
\text { et al. (1994) } \\
\text { [24] }\end{array}$ & 10 & 26 & 5 & 25 & 13 & 42 & Not reported & 8 - PTC \\
\hline $\begin{array}{l}\text { Dirikoc, A., } \\
\text { et al. (2017) } \\
{[25]}\end{array}$ & 34 & 34 & 24 & 8 & 46 & 14 & $\begin{array}{l}{ }^{a} 50- \\
\text { Nondiagnostic } \\
83- \\
\text { indeterminate } \\
13- \\
\text { malignant }\end{array}$ & $\begin{array}{l}118 \text { PTC } 7 \text { FTC } 6 \\
\text { Other }\end{array}$ \\
\hline $\begin{array}{l}\text { Mon, S. Y., } \\
\text { et al. (2018) } \\
{[9]}\end{array}$ & 13 & 12 & 33 & 100 & 8 & 8 & $\begin{array}{l}2 \text { - Benign } \\
1 \text { - AUS/FLUS }\end{array}$ & $\begin{array}{l}2 \text { FTC (Both were } \\
\text { FNAB benign) }\end{array}$ \\
\hline $\begin{array}{l}\text { Slijepcevic, N., } \\
\text { et al. (2015) } \\
{[26]}\end{array}$ & 16 & 6 & 7 & 14 & 16 & 21 & Not reported & 9 PTC \\
\hline $\begin{array}{l}\text { Tam, A., et al. } \\
(2019) \text { [27] }\end{array}$ & 25 & 17 & N/A & N/A & 10 & 28 & $\begin{array}{l}8 \text { - } \\
\text { Nondiagnostic } \\
51 \text { - Benign } \\
3 \text { - AUS/FLUS } \\
2 \text { - FN/SFN } \\
1 \text { - Malignant }\end{array}$ & $\begin{array}{l}10 \text { PTC } \\
4 \text { FTC } \\
\text { (7 malignancies } \\
\text { located outside } \\
\text { hot nodule) }\end{array}$ \\
\hline
\end{tabular}

TMNG toxic multinodular goiter, NTN non toxic nodule, MNG multinodular goiter, FNA fine needle aspirate, AUS/FLUS atypia of undetermined significance/follicular lesion of unknown significance, SM suspicious for malignancy, PTC papillary thyroid cancer, FTC follicular thyroid cancer, TTUMP thyroid tumour of unknown malignant potential, UTC undifferentiated thyroid cancer, Other includes Hurthle cell, medullary or undifferentiated

${ }^{a}$ Denotes cytology findings in all hyperthyroid patients

the carcinoma [23]. This study differed from the other four studies in that only pediatric patients were included. Given the increased malignancy risk reported in pediatric thyroid nodules compared to the adult population, malignancy rates found in pediatric populations cannot be extrapolated to the adult population [66]. In all 9 pediatric case reports there was sufficient evidence to support the presence of the thyroid carcinoma within the hot nodule as there was a single hot nodule being investigated, which correlated to location of the carcinoma

\begin{tabular}{|c|c|c|c|c|c|c|c|c|c|}
\hline Study or Subgroup & \multicolumn{2}{|c|}{ Toxic } & \multicolumn{2}{|c|}{ Non-toxic } & Weight & $\begin{array}{c}\text { Odds Ratio } \\
\text { M-H, Random, } 95 \% \mathrm{Cl}\end{array}$ & \multicolumn{3}{|c|}{$\begin{array}{c}\text { Odds Ratio } \\
\text { M-H, Random, } 95 \% \mathrm{CI}\end{array}$} \\
\hline Baser et al 2019 & 14 & 364 & 9 & 136 & $12.1 \%$ & $0.56[0.24,1.34]$ & & - & \\
\hline Corrias et al 2010 & 1 & 9 & 10 & 46 & $2.7 \%$ & $0.45[0.05,4.04]$ & & & \\
\hline Derosa et al 1994 & 8 & 143 & 56 & 399 & $13.9 \%$ & $0.36[0.17,0.78]$ & 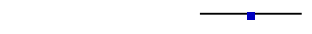 & & \\
\hline Dirikoc et al 2017 & 104 & 421 & 809 & 1908 & $29.5 \%$ & $0.45[0.35,0.57]$ & $\rightarrow$ & & \\
\hline Mon et al 2018 & 2 & 4 & 2 & 24 & $2.2 \%$ & $11.00[0.96,125.77]$ & & & \\
\hline Slijepcevic et al 2015 & 47 & 414 & 329 & 1750 & $26.7 \%$ & $0.55[0.40,0.77]$ & 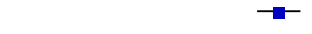 & & \\
\hline Tam et al 2019 & 7 & 73 & 101 & 265 & $12.9 \%$ & $0.17[0.08,0.39]$ & & & \\
\hline Total $(95 \% \mathrm{Cl})$ & & 1428 & & 4528 & $100.0 \%$ & $0.45[0.31,0.65]$ & & & \\
\hline Total events & 183 & & 1316 & & & & & & \\
\hline $\begin{array}{l}\text { Heterogeneity: } \mathrm{Tau}^{2}= \\
\text { Test for overall effect: }\end{array}$ & $\begin{array}{l}0.11 ; C h i \\
Z=4.21\end{array}$ & $\begin{array}{l}i^{2}=13 . \\
(P<0 .\end{array}$ & $\begin{array}{l}98, \mathrm{df}= \\
0001)\end{array}$ & $6(P$ & 03); & $57 \%$ & $0.01 \quad 0.1$ & 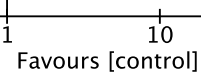 & 100 \\
\hline
\end{tabular}

Fig. 4 Pooled odds ratio for malignancy risk for all hot nodules including thyroid glands with single or multiple nodules 
Table 3 Summary of risk of bias assessment based on Newcastle-Ottawa Quality Assessment for Cohort Studies. A filled star denotes that a star has been awarded and that a study has been graded high quality. A blank star denotes that no star has been awarded and that the study has been graded as poor quality in that category. Total score indicates the total number of stars awarded in all categories. N/A denotes not applicable

\begin{tabular}{|c|c|c|c|c|c|c|c|c|}
\hline Cohort Studies & $\begin{array}{l}\text { Representativeness } \\
\text { of the exposed } \\
\text { cohort }\end{array}$ & $\begin{array}{c}\text { Selection of } \\
\text { the non- } \\
\text { exposed } \\
\text { cohort } \\
\end{array}$ & $\begin{array}{l}\text { Ascertainment } \\
\text { of exposure }\end{array}$ & $\begin{array}{c}\text { Demonstration that } \\
\text { outcome of interest was } \\
\text { not present at start of } \\
\text { study } \\
\end{array}$ & $\begin{array}{l}\text { Comparability of } \\
\text { cohorts on the } \\
\text { basis of the } \\
\text { design or analysis } \\
\end{array}$ & $\begin{array}{l}\text { Assessment of } \\
\text { outcome }\end{array}$ & Follow-up & Total score \\
\hline Baser, H., et al.(2019)[22] & $\hat{\imath}$ & $\star$ & $\star$ & $\star$ & $\star$ & $y$ & $\mathrm{~N} / \mathrm{A}$ & 5 \\
\hline $\begin{array}{l}\text { Corrias, A., et al. } \\
(2010) .[23]\end{array}$ & $\star$ & ـ & & 点 & 太 & > & N/A & 5 \\
\hline $\begin{array}{r}\text { Derosa, G., et al. } \\
(1994) .[24]\end{array}$ & $\hat{n}$ & $\star$ & & 太 & $\star$ & 7 & N/A & 5 \\
\hline $\begin{array}{r}\text { Dirikoc, A., et al. } \\
(2017) .[25]\end{array}$ & 鸟 & 市 & 虫 & 丈 & 太 & 7 & N/A & 4 \\
\hline $\begin{array}{l}\text { Mon, S. Y., et al. } \\
\text { (2018).[9] }\end{array}$ & $\hat{w}$ & t & A & 大 & 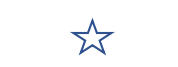 & 出 & N/A & 3 \\
\hline $\begin{array}{l}\text { Slijepcevic, N., et al. } \\
\text { (2015).[26] }\end{array}$ & $\hat{n}$ & $t$ & 茨 & 丈 & 丈 & & N/A & 4 \\
\hline Tam, A., et al. (2019)[27] & $\stackrel{s}{2}$ & t & 丈 & 丈 & 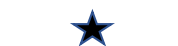 & & $N / A$ & 5 \\
\hline
\end{tabular}

on pathology [31-39]. In the 53 adult studies, nearly half (49\%) of the studies demonstrated sufficient evidence of the thyroid carcinoma within the hot nodule based on the presence of a single hot nodule on scintigraphy with the location of the carcinoma on pathology $[8,29,35$, $40-63,67-70]$. The other case reports were confounded by the presence of multiple thyroid nodules, and did not clearly delineate the location of the hot nodule on scintigraphy with pathology.

\section{Inclusion of microcarcinomas}

The percentage of carcinomas that were microcarcinomas in the seven included studies ranged from 9.5 to $100 \%$. The increased detection of papillary thyroid microcarcinomas (defined as tumours less than or equal to $10 \mathrm{~mm}$ ) has contributed significantly to the rise in incidence of thyroid cancer over the last few decades [71]. Microcarcinomas can be found in up to $35 \%$ of post-mortem studies [72]; most of these lesions are believed to be clinically insignificant. This has led to the current American Thyroid Association (ATA) recommendation to monitor sonographically suspicious or biopsy-proven papillary microcarcinomas, in an effort to prevent over-diagnosis and over-treatment of asymptomatic disease. In future studies, these low-risk microcarcinomas should either be analyzed separately, or excluded from the analysis of malignancy rate, to reflect the true risk of clinically significant malignancy in the study population.

\section{Mon et al. as the study outlier}

The use of molecular diagnostics is gaining increasing recognition in the assessment of indeterminate thyroid nodules [73]. A clear outlier in this review is a study that deliberately selected indeterminate nodules with TSHR mutations identified by molecular diagnostic testing of indeterminate thyroid nodules [9]. Among the 16 TSHR mutation positive patients with available histology, 3 patients had evidence of thyroid cancer. This study represents a highly selected group with an unusual way of diagnosing hot nodules that is very distinct from the other study populations. A major deficiency in this study is the lack of appropriate clinical diagnosis of hot nodules prior to FNA and molecular diagnostics. TSH was only measured in 27 of the 703 thyroid samples tested for mutations and rearrangements and scintigraphy was used in only 4 of the 6 patients with suppressed TSH. Thus, the OR for this group cannot be generalized for hot nodules.

\section{Limitations}

The notion that hot nodules rarely harbour malignancy is based on studies conducted in the 1960s to 1980s that examined scintigraphy in an undifferentiated patient population with thyroid nodules [12, 74]. At that time, the prevalence of thyroid nodules was estimated at 4 to $7 \%$ in the general adult population, with the risk of malignancy ranging from 10 to $20 \%[75,76]$. Since then, the prevalence of thyroid nodules has increased to 19$67 \%$ of the adult population based on increased use of and advances in ultrasonography, with similar malignancy rates of $8-16 \%[17,77]$.

A wide variation of incidence rate of malignancy was reported in both hot nodules and non-toxic nodules in our study. A major confounder in all studies was the 
Table 4 Summary of 62 case reports identified through our search strategy that reported thyroid carcinomas within hot nodules. (AFTN autonomously functioning thyroid nodules, TMNG toxic multinodular goiter, FTC follicular thyroid carcinoma, FVPTC follicular variant of papillary thyroid carcinoma, MTC medullary thyroid carcinoma, PTC papillary thyroid carcinoma)

\begin{tabular}{|c|c|c|c|c|c|c|c|}
\hline Authors & Year & $\begin{array}{l}\text { Study } \\
\text { Title }\end{array}$ & Journal Title & $\begin{array}{l}\text { Sample } \\
\text { size }\end{array}$ & Age & $\begin{array}{l}\text { Single or } \\
\text { multiple } \\
\text { toxic } \\
\text { nodules }\end{array}$ & $\begin{array}{l}\text { Type of thyroid } \\
\text { carcinoma }\end{array}$ \\
\hline$\overline{A b s, ~ R ., ~ e t ~ a l . ~}$ & 1991 & $\begin{array}{l}\text { Hyperfunctioning } \\
\text { metastatic follicular } \\
\text { thyroid-carcinoma in } \\
\text { Pendreds syndrome }\end{array}$ & Cancer & 1 & 66 & TMNG & $\overline{\text { FTC (metastatic) }}$ \\
\hline $\begin{array}{l}\text { Alaoui, N. I. } \\
\text { and N. Ben Rais }\end{array}$ & 2011 & $\begin{array}{l}\text { Association of } \\
\text { hyperthyroidism and } \\
\text { well-differentiated } \\
\text { thyroid carcinoma } \\
\text { (medullary excluded). } \\
\text { A propos of seven } \\
\text { cases. }\end{array}$ & $\begin{array}{l}\text { Medecine Nucleaire- } \\
\text { Imagerie } \\
\text { Fonctionnelle } \\
\text { Et Metabolique }\end{array}$ & 7 & 41.4 & $\begin{array}{l}4 \text { Graves' } \\
\text { disease, } 2 \\
\text { single } \\
\text { AFTN, } 1 \\
\text { TMNG }\end{array}$ & 5 PTC, 2 FTC \\
\hline $\begin{array}{l}\text { Appetecchia, M. } \\
\text { and M. Ducci [41] }\end{array}$ & 1998 & $\begin{array}{l}\text { Hyperfunctioning } \\
\text { differentiated thyroid } \\
\text { carcinoma. }\end{array}$ & $\begin{array}{l}\text { Journal of Endocrinological } \\
\text { Investigation }\end{array}$ & 1 & & AFTN & PTC \\
\hline $\begin{array}{l}\text { Ardito, G., } \\
\text { et al. [42] }\end{array}$ & 1997 & $\begin{array}{l}\text { Papillary thyroid } \\
\text { carcinoma mimicking } \\
\text { an autonomous } \\
\text { functioning nodule. }\end{array}$ & $\begin{array}{l}\text { European Journal of } \\
\text { Surgical Oncology }\end{array}$ & 1 & & AFTN & PTC \\
\hline $\begin{array}{l}\text { Bajja, M. Y., } \\
\text { et al. [43] }\end{array}$ & 2017 & $\begin{array}{l}\text { Mucinous carcinoma } \\
\text { of the thyroid: A case } \\
\text { report and review of } \\
\text { the literature. }\end{array}$ & Annales D Endocrinologie & 1 & 74 & AFTN & $\begin{array}{l}\text { Mucinous } \\
\text { carcinoma of the } \\
\text { thyroid }\end{array}$ \\
\hline $\begin{array}{l}\text { Barrande, } \\
\text { G., et al. }\end{array}$ & 1997 & $\begin{array}{l}\text { Two thyroid carcinomas } \\
\text { mimicking toxic } \\
\text { adenomas. }\end{array}$ & Presse Medicale & 2 & $\begin{array}{l}35 \text { and } \\
55\end{array}$ & AFTN & \\
\hline $\begin{array}{l}\text { Becker, F. O., } \\
\text { et al. }\end{array}$ & 1963 & $\begin{array}{l}\text { The occurrence of } \\
\text { carcinoma in "hot" } \\
\text { thyroid nodules. } \\
\text { Report of two cases. }\end{array}$ & $\begin{array}{l}\text { Annals of Internal } \\
\text { Medicine }\end{array}$ & 2 & & & \\
\hline Bircan, R., et al. & 2007 & $\begin{array}{l}\text { The second follicular } \\
\text { thyroid carcinoma } \\
\text { presenting as a hot } \\
\text { thyroid nodule with } \\
\text { a somatic 1486F TSH- } \\
\text { Receptor (TSHR) gene } \\
\text { mutation. }\end{array}$ & Hormone Research & 1 & & & FTC \\
\hline $\begin{array}{l}\text { Bitterman, A., } \\
\text { et al. [44] }\end{array}$ & 2006 & $\begin{array}{l}\text { Thyroid carcinoma } \\
\text { presenting as a hot } \\
\text { nodule. }\end{array}$ & $\begin{array}{l}\text { Otolaryngology - Head } \\
\& \text { Neck Surgery }\end{array}$ & 1 & $\begin{array}{l}66,57 \\
59\end{array}$ & $\begin{array}{l}\text { AFTN \& } \\
\text { TMNG }\end{array}$ & PTC \& 2 FTC \\
\hline $\begin{array}{l}\text { Bommireddipalli, } \\
\text { S., et al. [45] }\end{array}$ & 2010 & $\begin{array}{l}\text { Follicular variant of } \\
\text { papillary thyroid carcinoma } \\
\text { presenting } \\
\text { as a toxic nodule by } \\
\text { 1-123 scintigraphy. }\end{array}$ & Clinical Nuclear Medicine & 1 & 63 & AFTN & FVPTC \\
\hline $\begin{array}{l}\text { Bourasseau, l., } \\
\text { et al. }\end{array}$ & 2000 & $\begin{array}{l}\text { No evidence of } \\
\text { thyrotropin receptor } \\
\text { and } \mathrm{G}(\mathrm{s} \text { alpha) gene } \\
\text { mutation in high iodine } \\
\text { uptake thyroid } \\
\text { carcinoma. }\end{array}$ & Thyroid & 4 & $\begin{array}{l}\text { Mean } \\
\text { age } 41.1\end{array}$ & $\begin{array}{l}3 \text { AFTN, } 1 \\
\text { TMNG }\end{array}$ & 2 PTC and 2 FTC \\
\hline $\begin{array}{l}\text { Calimon, M. A. P. } \\
\text { and S. W. } \\
\text { Lim-Uy }[46]\end{array}$ & 2014 & $\begin{array}{l}\text { Papillary Thyroid } \\
\text { Carcinoma in an } \\
\text { Autonomous } \\
\text { Hyperfunctioning } \\
\text { Thyroid Nodule. }\end{array}$ & Endocrine Reviews & 1 & & AFTN & PTC \\
\hline Camacho, P., & 2000 & A Phe 486 thyrotropin & Thyroid & 1 & 49 & AFTN & FTC \\
\hline
\end{tabular}


Table 4 Summary of 62 case reports identified through our search strategy that reported thyroid carcinomas within hot nodules. (AFTN autonomously functioning thyroid nodules, TMNG toxic multinodular goiter, FTC follicular thyroid carcinoma, FVPTC follicular variant of papillary thyroid carcinoma, MTC medullary thyroid carcinoma, PTC papillary thyroid carcinoma) (Continued)

\begin{tabular}{|c|c|c|c|c|c|c|c|}
\hline Authors & Year & $\begin{array}{l}\text { Study } \\
\text { Title }\end{array}$ & Journal Title & $\begin{array}{l}\text { Sample } \\
\text { size }\end{array}$ & Age & $\begin{array}{l}\text { Single or } \\
\text { multiple } \\
\text { toxic } \\
\text { nodules }\end{array}$ & $\begin{array}{l}\text { Type of thyroid } \\
\text { carcinoma }\end{array}$ \\
\hline et al. [47] & & $\begin{array}{l}\text { receptor mutation in } \\
\text { an autonomously } \\
\text { functioning follicular } \\
\text { carcinoma that was } \\
\text { causing hyperthyroidism. }\end{array}$ & & & & & \\
\hline $\begin{array}{l}\text { Campenni, A., } \\
\text { et al. [32] }\end{array}$ & 2011 & $\begin{array}{l}\text { Follicular variant of } \\
\text { papillary thyroid } \\
\text { carcinoma presenting } \\
\text { as a toxic nodule in an } \\
\text { adolescent girl }\end{array}$ & $\begin{array}{l}\text { European Journal of } \\
\text { Nuclear Medicine and } \\
\text { Molecular Imaging }\end{array}$ & 1 & 15 & AFTN & PTC \\
\hline Castelli, V., et al. & 1994 & $\begin{array}{l}\text { Occurrence of papillary } \\
\text { carcinoma in a } \\
\text { hyperfunctioning thyroid } \\
\text { nodule: report of a case } \\
\text { and diagnostic } \\
\text { considerations }\end{array}$ & Thyroidology & 1 & & & PTC \\
\hline $\begin{array}{l}\text { Cirillo, R. L., Jr., } \\
\text { et al. [48] }\end{array}$ & 1998 & $\begin{array}{l}\text { Metastatic pure papillary } \\
\text { thyroid carcinoma } \\
\text { presenting as a toxic } \\
\text { hot nodule. }\end{array}$ & Clinical Nuclear Medicine & 1 & & AFTN & PTC (metastatic) \\
\hline $\begin{array}{l}\text { Clement, K., } \\
\text { et al. [49] }\end{array}$ & 1991 & $\begin{array}{l}\text { Thyroid cancer revealed } \\
\text { by an extinctive hot } \\
\text { nodule }\end{array}$ & Presse Medicale & 1 & 62 & & \\
\hline $\begin{array}{l}\text { Damle, N., } \\
\text { et al. [33] }\end{array}$ & 2011 & $\begin{array}{l}\text { Papillary carcinoma } \\
\text { masquerading as clinically } \\
\text { toxic adenoma in very } \\
\text { young children. }\end{array}$ & $\begin{array}{l}\text { Journal of Pediatric } \\
\text { Endocrinology \& Metabolism }\end{array}$ & 2 & $\begin{array}{l}6 \\
\text { months } \\
\text { and } 5 y\end{array}$ & AFTN & PTC \\
\hline $\begin{array}{l}\text { De Rosa, G., } \\
\text { et al. [50] }\end{array}$ & 1990 & $\begin{array}{l}\text { Thyroid carcinoma } \\
\text { mimicking a toxic } \\
\text { adenoma. }\end{array}$ & $\begin{array}{l}\text { European Journal of } \\
\text { Nuclear Medicine }\end{array}$ & & & AFTN & \\
\hline $\begin{array}{l}\text { Ducci, M., } \\
\text { et al. [34] }\end{array}$ & 1996 & $\begin{array}{l}\text { Differentiated carcinoma } \\
\text { in autonomously functioning } \\
\text { thyroid nodule: case report. }\end{array}$ & $\begin{array}{l}\text { Acta otorhinolaryngologica } \\
\text { Italica: organo ufficiale della } \\
\text { Società italiana di otorinolaringologia } \\
\text { e chirurgia cervico-facciale }\end{array}$ & 1 & 13 & AFTN & PTC \\
\hline $\begin{array}{l}\text { Einert, A., } \\
\text { et al. [51] }\end{array}$ & 1995 & $\begin{array}{l}\text { A combination of unifocal } \\
\text { thyroid autonomy and } \\
\text { follicular carcinoma - A } \\
\text { case report }\end{array}$ & Radiologe & 1 & 53 & AFTN & FTC \\
\hline $\begin{array}{l}\text { Emmrich, P., } \\
\text { et al. [52] }\end{array}$ & 2001 & $\begin{array}{l}\text { Unifocal autonomous } \\
\text { thyroid nodule and } \\
\text { carcinoma. }\end{array}$ & Zentralblatt Fur Chirurgie & 2 & & AFTN & FTC and PTC \\
\hline $\begin{array}{l}\text { Foppiani, L., } \\
\text { et al. [53] }\end{array}$ & 2005 & $\begin{array}{l}\text { Heterogeneous malignancy } \\
\text { in toxic thyroid nodules }\end{array}$ & $\begin{array}{l}\text { Journal of Endocrinological } \\
\text { Investigation }\end{array}$ & 3 & $\begin{array}{l}68,38 \\
\& 62\end{array}$ & $\begin{array}{l}2 \text { AFTN, } 1 \\
\text { TMNG }\end{array}$ & $3 \mathrm{FTC}$ \\
\hline $\begin{array}{l}\text { Fuhrer, D., } \\
\text { et al. [54] }\end{array}$ & 2003 & $\begin{array}{l}\text { Two somatic TSH receptor } \\
\text { mutations in a patient with } \\
\text { toxic metastasising follicular } \\
\text { thyroid carcinoma and non- } \\
\text { functional lung metastases. }\end{array}$ & Endocrine-Related Cancer & 1 & 59 & TMNG & FTC \\
\hline Fujimoto, Y., et al. & 1972 & $\begin{array}{l}\text { Occurrence of papillary } \\
\text { carcinoma in hyperfunctioning } \\
\text { thyroid nodule. Report of a } \\
\text { case. }\end{array}$ & Endocrinologia Japonica & 1 & & & \\
\hline $\begin{array}{l}\text { Fukata, S., } \\
\text { et al. [55] }\end{array}$ & 1987 & $\begin{array}{l}\text { Thyroid carcinoma and hot } \\
\text { nodule }\end{array}$ & $\begin{array}{l}\text { European Journal of } \\
\text { Nuclear Medicine }\end{array}$ & 1 & 70 & AFTN & PTC \\
\hline Gardner, D. and & 2014 & A rare cause of hyperthyroidism: & BMJ Case Reports & 1 & 66 & TMNG & FVPTC \\
\hline
\end{tabular}


Table 4 Summary of 62 case reports identified through our search strategy that reported thyroid carcinomas within hot nodules. (AFTN autonomously functioning thyroid nodules, TMNG toxic multinodular goiter, FTC follicular thyroid carcinoma, FVPTC follicular variant of papillary thyroid carcinoma, MTC medullary thyroid carcinoma, PTC papillary thyroid carcinoma) (Continued)

\begin{tabular}{|c|c|c|c|c|c|c|c|}
\hline Authors & Year & $\begin{array}{l}\text { Study } \\
\text { Title }\end{array}$ & Journal Title & $\begin{array}{l}\text { Sample } \\
\text { size }\end{array}$ & Age & $\begin{array}{l}\text { Single or } \\
\text { multiple } \\
\text { toxic } \\
\text { nodules }\end{array}$ & $\begin{array}{l}\text { Type of thyroid } \\
\text { carcinoma }\end{array}$ \\
\hline S. C. Ho & & functioning thyroid metastases & & & & & \\
\hline $\begin{array}{l}\text { Gozu, H. } \\
\text { et al. [67] }\end{array}$ & 2004 & $\begin{array}{l}\text { Does a Leu } 512 \text { Arg thyrotropin } \\
\text { receptor mutation cause an } \\
\text { autonomously functioning } \\
\text { papillary carcinoma? }\end{array}$ & Thyroid & 1 & $?$ & TMNG & PTC \\
\hline Kim, T. S., et al. & 2007 & $\begin{array}{l}\text { A rare case of hyperfunctioning } \\
\text { papillary carcinoma of the } \\
\text { thyroid gland }\end{array}$ & Acta Oto-Laryngologica & 1 & 32 & AFTN & FVPTC \\
\hline $\begin{array}{l}\text { Kuan, Y. C. } \\
\text { and F. H. Tan }\end{array}$ & 2014 & $\begin{array}{l}\text { Thyroid papillary carcinoma } \\
\text { in a 'hot' thyroid nodule. }\end{array}$ & Qjm & 1 & 60 & AFTN & FVPTC \\
\hline $\begin{array}{l}\text { Lado-Abeal J. } \\
\text { et al [68] }\end{array}$ & 2010 & $\begin{array}{l}\text { Identification of a paired } \\
\text { box gene 8-peroxisome } \\
\text { proliferator-activated receptor } \\
\text { gamma (PAX8-PPAR gamma) } \\
\text { rearrangement mosaicism in } \\
\text { a patient with an autonomous } \\
\text { functioning follicular thyroid } \\
\text { carcinoma bearing an activating } \\
\text { mutation in the TSH receptor }\end{array}$ & Endocrine-Related Cancer & 1 & 55 & TMNG & FTC \\
\hline Lima, M. J., et al. & 2018 & $\begin{array}{l}\text { Autonomously hyperfunctioning } \\
\text { cystic nodule harbouring } \\
\text { thyroid carcinoma - Case report } \\
\text { and literature review." }\end{array}$ & $\begin{array}{l}\text { International Journal of } \\
\text { Surgery Case Reports }\end{array}$ & 1 & 49 & AFTN & FVPTC \\
\hline $\begin{array}{l}\text { Majima, T., } \\
\text { et al. [56] }\end{array}$ & 2005 & $\begin{array}{l}\text { Papillary thyroid carcinoma } \\
\text { without metastases manifesting } \\
\text { as an autonomously functioning } \\
\text { thyroid nodule. }\end{array}$ & Endocrine Journal & 1 & 59 & AFTN & PTC \\
\hline $\begin{array}{l}\text { Marcelino, M., } \\
\text { et al. [28] }\end{array}$ & 2014 & $\begin{array}{l}\text { Anaplastic carcinoma and } \\
\text { toxic multinodular goiter: an } \\
\text { unusual presentation }\end{array}$ & European Thyroid Journal & 1 & 70 & TMNG & $\begin{array}{l}\text { Anaplastic } \\
\text { thyroid } \\
\text { carcinoma }\end{array}$ \\
\hline $\begin{array}{l}\text { Mircescu, } \mathrm{H}_{\text {., }} \\
\text { et al. [35] }\end{array}$ & 2000 & $\begin{array}{l}\text { Hyperfunctioning malignant } \\
\text { thyroid nodule in an } \\
11 \text {-year-old girl: pathologic } \\
\text { and molecular studies. }\end{array}$ & Journal of Pediatrics & 1 & 11 & AFTN & PTC \\
\hline $\begin{array}{l}\text { Mirfakhraee, } \\
\text { S., et al. [8] }\end{array}$ & 2013 & $\begin{array}{l}\text { A solitary hyperfunctioning } \\
\text { thyroid nodule harboring } \\
\text { thyroid carcinoma: review } \\
\text { of the literature }\end{array}$ & Thyroid research & 1 & 29 & AFTN & FTC \\
\hline Nagai, G. R., et al. & 1987 & $\begin{array}{l}\text { Scintigraphic hot nodules } \\
\text { and thyroid carcinoma }\end{array}$ & Clinical Nuclear Medicine & 3 & & & 2 FTC and 1 PTC \\
\hline $\begin{array}{l}\text { Nemec, J., } \\
\text { et al. [57] }\end{array}$ & 1980 & $\begin{array}{l}\text { Metastatic thyroid cancer } \\
\text { with severe hyperthyroidism } \\
\text { mimicking independent } \\
\text { hyperfunctioning thyroid } \\
\text { adenoma, showing transition } \\
\text { to water-clear-tumour. }\end{array}$ & Endokrinologie & 1 & & AFTN & FTC (metastatic) \\
\hline $\begin{array}{l}\text { Niepomniszcze, } \\
\text { H., et al. [58] }\end{array}$ & 2006 & $\begin{array}{l}\text { Follicular carcinoma } \\
\text { presenting as autonomous } \\
\text { functioning thyroid nodule } \\
\text { and containing an activating } \\
\text { mutation of the TSH receptor } \\
\text { (T620l) and a mutation of } \\
\text { the Ki-RAS (G12C) genes. }\end{array}$ & Thyroid & 1 & 64 & AFTN & FTC \\
\hline $\begin{array}{l}\text { Nishida, A. T., } \\
\text { et al. [59] }\end{array}$ & 2008 & $\begin{array}{l}\text { Multifocal hyperfunctioning } \\
\text { thyroid carcinoma without } \\
\text { metastases. }\end{array}$ & Auris, Nasus, Larynx & 1 & 62 & TMNG & PTC \\
\hline
\end{tabular}


Table 4 Summary of 62 case reports identified through our search strategy that reported thyroid carcinomas within hot nodules. (AFTN autonomously functioning thyroid nodules, TMNG toxic multinodular goiter, FTC follicular thyroid carcinoma, FVPTC follicular variant of papillary thyroid carcinoma, MTC medullary thyroid carcinoma, PTC papillary thyroid carcinoma) (Continued)

\begin{tabular}{|c|c|c|c|c|c|c|c|}
\hline Authors & Year & $\begin{array}{l}\text { Study } \\
\text { Title }\end{array}$ & Journal Title & $\begin{array}{l}\text { Sample } \\
\text { size }\end{array}$ & Age & $\begin{array}{l}\text { Single or } \\
\text { multiple } \\
\text { toxic } \\
\text { nodules }\end{array}$ & $\begin{array}{l}\text { Type of thyroid } \\
\text { carcinoma }\end{array}$ \\
\hline $\begin{array}{l}\text { Polyzos, S. A. and } \\
\text { D. G. Goulis [30] }\end{array}$ & 2011 & $\begin{array}{l}\text { Coincidental thyroid papillary } \\
\text { microcarcinoma in a patient } \\
\text { treated for a toxic adenoma } \\
\text { of the thyroid. }\end{array}$ & Archives of Iranian Medicine & 1 & & AFTN & $\begin{array}{l}\text { PTC } \\
\text { (microcarcinoma) }\end{array}$ \\
\hline $\begin{array}{l}\text { Rees, D. O., } \\
\text { et al. [36] }\end{array}$ & 2015 & $\begin{array}{l}\text { Follicular variant of papillary } \\
\text { thyroid carcinoma: an unusual } \\
\text { cause of thyrotoxicosis. }\end{array}$ & BMJ Case Reports & 1 & 16 & AFTN & FVPTC \\
\hline Rivas, l., et al. [29] & 1995 & $\begin{array}{l}\text { Medullary thyroid carcinoma } \\
\text { mimicking an autonomous } \\
\text { functioning nodule }\end{array}$ & $\begin{array}{l}\text { Journal of } \\
\text { Endocrinological } \\
\text { Investigation }\end{array}$ & 1 & 42 & AFTN & MTC \\
\hline $\begin{array}{l}\text { Rubenfeld, S. and } \\
\text { T. M. Wheeler }\end{array}$ & 1988 & $\begin{array}{l}\text { Thyroid cancer presenting } \\
\text { as a hot thyroid nodule: } \\
\text { report of a case and review } \\
\text { of the literature }\end{array}$ & Thyroidology & 1 & & AFTN & \\
\hline $\begin{array}{l}\text { Ruggeri, R. M., } \\
\text { et al. [37] }\end{array}$ & 2013 & $\begin{array}{l}\text { Follicular variant of papillary } \\
\text { thyroid carcinoma presenting } \\
\text { as toxic nodule in an adolescent: } \\
\text { coexistent polymorphism of } \\
\text { the TSHR and Gsalpha genes. }\end{array}$ & Thyroid & 1 & 15 & AFTN & FVPTC \\
\hline $\begin{array}{l}\text { Russo, D. } \\
\text { et al. [70] }\end{array}$ & 1997 & $\begin{array}{l}\text { Detection of an activating } \\
\text { mutation of the thyrotropin } \\
\text { receptor in a case of an } \\
\text { autonomously hyperfunctioning } \\
\text { thyroid insular carcinoma }\end{array}$ & JCEM & 1 & 60 & AFTN & $\begin{array}{l}\text { Insular } \\
\text { carcinoma }\end{array}$ \\
\hline $\begin{array}{l}\text { Russo, D. } \\
\text { et al. [69] }\end{array}$ & 1999 & $\begin{array}{l}\text { A Val } 677 \text { activating mutation } \\
\text { of the thyrotropin receptor } \\
\text { in a Hurthle cell thyroid } \\
\text { carcinoma associated with } \\
\text { thyrotoxicosis }\end{array}$ & Thyroid & 1 & 42 & AFTN & $\begin{array}{l}\text { Hurthle cell } \\
\text { carcinoma }\end{array}$ \\
\hline $\begin{array}{l}\text { Sablayrolles, } \\
\text { B., et al. }\end{array}$ & 1983 & $\begin{array}{l}\text { Thyroid carcinoma } \\
\text { presenting as a hot nodule } \\
\text { in a child }\end{array}$ & $\begin{array}{l}\text { Archives Francaises } \\
\text { De Pediatrie }\end{array}$ & 1 & & & \\
\hline Salih, A. M., et al. & 2016 & $\begin{array}{l}\text { Hyperfunctioning papillary } \\
\text { thyroid carcinoma: A case } \\
\text { report with literature review. }\end{array}$ & $\begin{array}{l}\text { nternational Journal } \\
\text { of Surgery Case Reports }\end{array}$ & 1 & 40 & TMNG & PTC \\
\hline $\begin{array}{l}\text { Sandler, M. P., } \\
\text { et al. [60] }\end{array}$ & 1988 & $\begin{array}{l}\text { Thyroid carcinoma } \\
\text { masquerading as a solitary } \\
\text { benign hyperfunctioning } \\
\text { nodule }\end{array}$ & Clinical Nuclear Medicine & 1 & & AFTN & PTC \\
\hline Sato, Y., et al. & 1998 & $\begin{array}{l}\text { Hyperfunctioning thyroid } \\
\text { adenoma concomitant with } \\
\text { papillary thyroid carcinoma, } \\
\text { follicular thyroid adenoma } \\
\text { and primary hyperparathyroidism. }\end{array}$ & Endocrine Journal & 1 & 67 & TMNG & PTC \\
\hline Schmidt, S., et al. & 2016 & $\begin{array}{l}\text { Hyperfunctioning thyroid } \\
\text { nodules (toxic adenoma)- } \\
\text { underestimated risk of } \\
\text { malignancy? }\end{array}$ & $\begin{array}{l}\text { Langenbeck's Archives } \\
\text { of Surgery }\end{array}$ & 1 & 72 & TMNG & PTC \\
\hline $\begin{array}{l}\text { Schneider, P. W., } \\
\text { et al. [61] }\end{array}$ & 2000 & $\begin{array}{l}\text { A clear cell variant of } \\
\text { follicular carcinoma } \\
\text { presenting as an } \\
\text { autonomously functioning } \\
\text { thyroid nodule. }\end{array}$ & Thyroid & 1 & & AFTN & FTC \\
\hline Sevinc, B., et al. & 2018 & $\begin{array}{l}\text { Papillary thyroid carcinoma } \\
\text { after radioactive iodine } \\
\text { treatment for toxic thyroid }\end{array}$ & Marmara Medical Journal & 1 & 55 & AFTN & PTC \\
\hline
\end{tabular}


Table 4 Summary of 62 case reports identified through our search strategy that reported thyroid carcinomas within hot nodules. (AFTN autonomously functioning thyroid nodules, TMNG toxic multinodular goiter, FTC follicular thyroid carcinoma, FVPTC follicular variant of papillary thyroid carcinoma, MTC medullary thyroid carcinoma, PTC papillary thyroid carcinoma) (Continued)

\begin{tabular}{|c|c|c|c|c|c|c|c|}
\hline Authors & Year & $\begin{array}{l}\text { Study } \\
\text { Title }\end{array}$ & Journal Title & $\begin{array}{l}\text { Sample } \\
\text { size }\end{array}$ & Age & $\begin{array}{l}\text { Single or } \\
\text { multiple } \\
\text { toxic } \\
\text { nodules }\end{array}$ & $\begin{array}{l}\text { Type of thyroid } \\
\text { carcinoma }\end{array}$ \\
\hline & & nodule: Case report. & & & & & \\
\hline $\begin{array}{l}\text { Siddiqui, A. R. } \\
\text { and S. } \\
\text { Karanauskas [38] }\end{array}$ & 1995 & $\begin{array}{l}\text { Hurthle cell-carcinoma in } \\
\text { an autonomous thyroid } \\
\text { nodule in an adolescent }\end{array}$ & Pediatric Radiology & 1 & 16 & AFTN & $\begin{array}{l}\text { Hurthle cell } \\
\text { carcinoma }\end{array}$ \\
\hline Simsek, E., et al. & 2014 & $\begin{array}{l}\text { Metastatic Papillary } \\
\text { Thyroid Carcinoma in an } \\
\text { Autonomous Hyperfunctioning } \\
\text { Thyroid Nodule in an Adolescent }\end{array}$ & Endocrine Reviews & 1 & & AFTN & PTC (metastatic) \\
\hline Sobel, R. J., et al. & 1985 & $\begin{array}{l}\text { Papillary carcinoma and the } \\
\text { solitary autonomously } \\
\text { functioning nodule of } \\
\text { the thyroid. }\end{array}$ & $\begin{array}{l}\text { Israel Journal of } \\
\text { Medical Sciences }\end{array}$ & 3 & & AFTN & PTC \\
\hline $\begin{array}{l}\text { Stahl, A., } \\
\text { et al. [62] }\end{array}$ & 2002 & $\begin{array}{l}\text { Differentiated thyroid } \\
\text { carcinoma in a scintigraphically } \\
\text { hot nodule: diagnosis and } \\
\text { interdisciplinary therapeutical } \\
\text { approach. }\end{array}$ & $\begin{array}{l}\text { Wiener Klinische } \\
\text { Wochenschrift }\end{array}$ & 1 & 57 & AFTN & $\begin{array}{l}\text { Metastatic } \\
\text { differentiated } \\
\text { thyroid } \\
\text { carcinoma }\end{array}$ \\
\hline $\begin{array}{l}\text { Tangari, A., } \\
\text { et al. [31] }\end{array}$ & 2011 & $\begin{array}{l}\text { Hot nodule harboring a } \\
\text { papillary microcarcinoma in a } \\
\text { girl from an iodine sufficient } \\
\text { area. }\end{array}$ & $\begin{array}{l}\text { Hormone Research } \\
\text { in Paediatrics }\end{array}$ & 1 & 3 & AFTN & $\begin{array}{l}\text { PTC } \\
\text { (microcarcinoma) }\end{array}$ \\
\hline $\begin{array}{l}\text { Tfayli, H. M., } \\
\text { et al. [39] }\end{array}$ & 2010 & $\begin{array}{l}\text { Papillary thyroid carcinoma } \\
\text { in an autonomous } \\
\text { hyperfunctioning thyroid } \\
\text { nodule: case report and } \\
\text { review of the literature }\end{array}$ & Thyroid & 1 & 11 & AFTN & PTC \\
\hline Uludag, M., et al. & 2008 & $\begin{array}{l}\text { Autonomously functioning } \\
\text { thyroid nodule treated with } \\
\text { radioactive iodine and later } \\
\text { diagnosed as papillary } \\
\text { thyroid cancer. }\end{array}$ & Hormones & 1 & 36 & AFTN & $\begin{array}{l}\text { PTC (columnar } \\
\text { type) }\end{array}$ \\
\hline $\begin{array}{l}\text { Wong, C. P., } \\
\text { et al. [63] }\end{array}$ & 2003 & $\begin{array}{l}\text { Thyrotoxicosis: a rare } \\
\text { presenting symptom of } \\
\text { Hurthle cell carcinoma of } \\
\text { the thyroid. }\end{array}$ & $\begin{array}{l}\text { Clinical Nuclear } \\
\text { Medicine }\end{array}$ & 1 & & AFTN & $\begin{array}{l}\text { Hurthle cell } \\
\text { carcinoma }\end{array}$ \\
\hline
\end{tabular}

inclusion of only patients undergoing partial or total thyroidectomy. Given that these patients were selected for thyroidectomy instead of treatment with antithyroid medication or radioactive iodine therapy, there exists the potential for a selection bias influencing our primary outcome of the true rate of malignancy in hot nodules. For example, in the cohort of patients selected for thyroidectomy, as opposed to monitoring or radioactive iodine therapy, one reason for surgical intervention could be a high-risk sonographic pattern in the index hot nodule or other concurrent non-index lesions. In this cohort, it would be logical to see a higher rate of malignancy than expected. Furthermore, rate of malignancy may also vary based on geographical location, and local clinical practices (predominance of surgical resection versus treatment with radioactive iodine).

\section{Summary}

Current guidelines for the differential diagnosis and treatment of thyroid nodules recommend clinical assessment and measurement of serum TSH levels [5, 78]. In patients with low TSH levels, the next recommendation involves thyroid scintigraphy with further malignancy risk stratification applied only to non-toxic nodules. The $\mathrm{AACE} / \mathrm{AME}$ guideline recognise that in geographic regions with past or present iodine deficiency scintigraphy is used as part of the evaluation of patients with MNG and that TSH may remain unsuppressed even when autonomy is present [4].

Based on this systematic review, we were unable to identify a prospective study that directly compared the malignancy risk of hot nodules with non-toxic nodules in adults. Also, each included study contained 
one or more limitations that negatively impacted its ability to answer our primary question (see Table 1). The lack of a well conducted prospective study assessing the malignancy risk in all patients with hot nodules, together with the identification of 62 case reports identifying thyroid carcinomas within hot nodules, challenges the hypothesis that hot nodules are rarely malignant.

With limitations in mind, this systematic review demonstrates that the odds of malignancy in hot nodules are reduced by $49-62 \%$ compared to non-toxic nodules. However, the overall rate of malignancy observed in hot nodules is higher than expected. Traditionally, hot thyroid nodules were thought to rarely harbour malignancy with rates reported as low as $0.34 \%$ [14]. Higher incidence of malignancy in hot nodules was observed in the seven included studies ranging from 10 to $34 \%$ (Table 1) [9, 23-26]. FNA biopsy results available for 4 studies demonstrate a low diagnostic yield of FNA cytology for the diagnosis of malignancy (Table 2). A large number of studies were excluded from analysis for the inclusion of only hot nodules without a comparison with non-toxic nodules (Supplemental Table 3) [7, 10, 13-15, 65, 72, 79-98]. Furthermore, the search strategy identified 62 case reports that described the presence of thyroid malignancy within a hot nodule (Table 4).

In summary, this systematic review highlights the need for further research into the malignancy risk assessment of hot nodules. There is sufficient evidence to question the notion that hot nodules rarely harbour thyroid cancer. To adequately address this question, a study of adult patients would need to incorporate both scintigraphically hot and non-toxic nodules, resected for any indication, with histologic correlation of the location of the nodule by preoperative imaging (ultrasound and scintigraphy) and histologic examination, and exclusion of low-risk papillary microcarcinomas. Furthermore, if hot nodules were to be subjected to further assessment, the ultrasonographic malignancy risk stratification would need to be assessed for this specific population.

\section{Supplementary Information}

The online version contains supplementary material available at https://doi. org/10.1186/s13044-021-00094-1.

Additional file 1: Supplemental Table 1. Summary of data points extracted. Supplemental Table 2. Summary of excluded full text articles. Supplemental Table 3. Reasons for article exclusion. Supplemental Table 4. Incidence of malignancy in hot nodules reported in studies examining only hot nodules. Supplemental Figure 1. Pooled odds ratio of combined hot nodules compared with non-toxic nodules excluding pediatric patients and those with known TSHR mutations

\section{Abbreviations}

TMNG: Toxic multinodular goiters; TSH: Thyrotropin/Thyroid-stimulating hormone; PRISMA: Preferred reporting items for systematic review and metaanalyses; FNAB: Fine needle aspiration biopsy; NTN: Non-toxic nodules;

MNG: Multinodular goiters; PTC: Papillary thyroid carcinomas; fVPTC: Follicular variant of papillary thyroid carcinomas; ATA: American Thyroid Association;

AACE/ACE/AME: Amercian Association of Clinical Endocrinologist (AACE),

American College of Endocrinology (ACE) and Associazione Medici

Endocrinologi (AME)

Acknowledgements

Not applicable.

\section{Authors' contributions}

LWL and RP conceived and designed the study. HLR performed the search. LWL and AS performed the data extraction. ADF performed the data analysis. LWL wrote the initial manuscript. LWL, SG, ADF, AS, HLR, DMR, and RP all participated in the critical revision of the manuscript and contributed to the final version. The author(s) read and approved the final manuscript.

Funding

No funding sources were utilized.

\section{Availability of data and materials}

All data generated or analysed during this study are included in this published article and its supplementary information files.

\section{Ethics approval and consent to participate}

Not applicable.

Consent for publication

Not applicable.

\section{Competing interests}

The authors declare that they have no competing interests.

\section{Author details}

${ }^{1}$ Department of Medicine, Cumming School of Medicine, University of Calgary, Calgary, Canada. 'Section of Endocrinology and Metabolism, Department of Medicine, Cumming School of Medicine, University of Calgary, Calgary, Canada. ${ }^{3}$ Arnie Charbonneau Cancer Institute, Cumming School of Medicine, University of Calgary, Calgary, AB, Canada. ${ }^{4}$ Clinical Medicine. Health Sciences Library, University of Calgary, Calgary, Canada. ${ }^{5}$ Department of Community Health Sciences, Cumming School of Medicine, University of Calgary, Calgary, AB, Canada. ${ }^{6}$ Departments of Oncology, Pathology, and Laboratory Medicine, Biochemistry and Molecular Biology, Cumming School of Medicine, University of Calgary, Calgary, Canada.

Received: 10 September 2020 Accepted: 1 February 2021

Published online: 25 February 2021

\section{References}

1. Corvilain B. The natural history of thyroid autonomy and hot nodules. Ann Endocrinol (Paris). 2003;64(1):17-22.

2. Moreno-Reyes R, Kyrilli A, Lytrivi M, Bourmorck C, Chami R, Corvilain B. Is there still a role for thyroid scintigraphy in the workup of a thyroid nodule in the era of fine needle aspiration cytology and molecular testing? F1000Res. 2016;5:1-8.

3. Sandrock D, Olbricht T, Emrich D, Benker G, Reinwein D. Long-term followup in patients with autonomous thyroid adenoma. Acta Endocrinol. 1993; 128(1):51-5.

4. Gharib H, Papini E, Garber JR, Duick DS, Harrell RM, Hegedus L, et al. American Association of Clinical Endocrinologists, American College of Endocrinology, and Associazione Medici Endocrinologi medical guidelines for clinical practice for the diagnosis and Management of Thyroid Nodules-2016 update. Endocr Pract. 2016;22(5):622-39.

5. Haugen BR, Alexander EK, Bible KC, Doherty GM, Mandel SJ, Nikiforov YE, et al. 2015 American Thyroid Association management guidelines for adult patients with thyroid nodules and differentiated thyroid Cancer: the American Thyroid Association guidelines task force on thyroid nodules and differentiated thyroid Cancer. Thyroid. 2016;26(1):1-133. 
6. Pazaitou-Panayiotou K, Michalakis K, Paschke R. Thyroid cancer in patients with hyperthyroidism. Horm Metab Res. 2012;44(4):255-62

7. Lee ES, Kim JH, Na DG, Paeng JC, Min HS, Choi SH, et al. Hyperfunction thyroid nodules: their risk for becoming or being associated with thyroid cancers. Korean J Radiol. 2013;14(4):643-52.

8. Mirfakhraee S, Mathews D, Peng L, Woodruff S, Zigman JM. A solitary hyperfunctioning thyroid nodule harboring thyroid carcinoma: review of the literature. Thyroid Res. 2013;6(1):7.

9. Mon SY, Riedlinger G, Abbott CE, Seethala R, Ohori NP, Nikiforova MN, et al. Cancer risk and clinicopathological characteristics of thyroid nodules harboring thyroid-stimulating hormone receptor gene mutations. Diagn Cytopathol. 2018;46(5):369-77.

10. Eszlinger M, Niedziela M, Typlt E, Jaeschke H, Huth S, Schaarschmidt J, et al. Somatic mutations in 33 benign and malignant hot thyroid nodules in children and adolescents. Mol Cell Endocrinol. 2014;393(1-2): 39-45.

11. Ashcraft MW, Van Herle AJ. Management of thyroid nodules. II: scanning techniques, thyroid suppressive therapy, and fine needle aspiration. Head Neck Surg. 1981;3(4):297-322.

12. Ashcraft MW, Van Herle AJ. Management of thyroid nodules. I: history and physical examination, blood tests, X-ray tests, and ultrasonography. Head Neck Surg. 1981;3(3):216-30.

13. Dirikoc A, Polat SB, Kandemir Z, Aydin C, Ozdemir D, Dellal FD, et al. Comparison of ultrasonography features and malignancy rate of toxic and nontoxic autonomous nodules: a preliminary study. Ann Nucl Med. 2015; 29(10):883-9.

14. Erdogan MF, Anil C, Ozer D, Kamel N, Erdogan G. Is it useful to routinely biopsy hot nodules in iodine deficient areas? J Endocrinol Investig. 2003; 26(2):128-31.

15. Ikekubo K, Hino M, Ito H, Otani M, Yamaguchi H, Saiki Y, et al. Thyroid carcinoma in solitary hot thyroid lesions on Tc-99m sodium pertechnetate scans. Ann Nucl Med. 1989;3(1):31-6.

16. Giuffrida D, Gharib H. Controversies in the management of cold, hot, and occult thyroid nodules. Am J Med. 1995;99(6):642-50

17. Burman KD, Wartofsky L. Clinical Practice. Thyroid nodules. N Engl J Med. 2015;373(24):2347-56.

18. Moher D, Liberati A, Tetzlaff J, Altman DG, Group P. Preferred reporting items for systematic reviews and meta-analyses: the PRISMA statement. Ann Intern Med. 2009;151(4):264-9 W64.

19. Higgins JP, Thompson SG. Quantifying heterogeneity in a meta-analysis. Stat Med. 2002;21(11):1539-58.

20. Egger M, Davey Smith G, Altman D. Systematic reviews in health care: meta-analysis in context. 2nd ed. London: BMJ Publishing Group; 2001.

21. Wells G, Shea B, O'Connell D, Peterson J, Welch V, Losos M, et al. The Newcastle-Ottawa Scale (NOS) for assessing the quality of nonrandomised studies in meta-analyses http://www.ohrica/programs/clinical_ epidemiology/oxfordasp.

22. Baser H, Topaloglu O, Bilginer MC, Ulusoy S, Kilicarslan A, Ozdemir E, et al. Are cytologic and histopathologic features of hot thyroid nodules different from cold thyroid nodules? Diagn Cytopathol. 2019;47(9):898-903.

23. Corrias A, Mussa A, Baronio F, Arrigo T, Salerno M, Segni M, et al. Diagnostic features of thyroid nodules in pediatrics. Arch Pediatr Adolesc Med. 2010; 164(8):714-9.

24. Derosa G, Testa A, Giacomini D, Liverotti J, Verzi A, Dugo D, et al. Prevalence of thyroid-carcinoma in toxic goiter. J Exp Clin Cancer Res. 1994;13(2):169-73.

25. Dirikoc A, Faki S, Baser H, Ozdemir D, Aydin C, Ersoy R, et al. Thyroid malignancy risk in different clinical thyroid diseases. Turk. 2017:47(5): 1509-19.

26. Slijepcevic N, Zivaljevic V, Marinkovic J, Sipetic S, Diklic A, Paunovic I. Retrospective evaluation of the incidental finding of 403 papillary thyroid microcarcinomas in 2466 patients undergoing thyroid surgery for presumed benign thyroid disease. BMC Cancer. 2015;15:330.

27. Tam AA, Ozdemir D, Alkan A, Yazicioglu O, Yildirim N, Kilicyazgan A, et al. Toxic nodular goiter and thyroid cancer: is hyperthyroidism protective against thyroid cancer? Surgery (United States). 2019;166(3):356-61.

28. Marcelino M, Marques $P$, Lopes $L$, Leite $V$, de Castro JJ. Anaplastic carcinoma and toxic multinodular goiter: an unusual presentation. Eur. 2014;3(4):278-82.

29. Rivas I, Gutierrez C, Vendrell J, Razkin S, Richart C. Medullary thyroid carcinoma mimicking an autonomous functioning nodule. J Endocrinol Investig. 1995;18(3):224-7.
30. Polyzos SA, Goulis DG. Coincidental thyroid papillary microcarcinoma in a patient treated for a toxic adenoma of the thyroid. Arch Iran Med. 2011; 14(2):149-51.

31. Tangari A, Solarz HM, Farias J, Bignon H, Morano P, Papendieck P. Hot nodule harboring a papillary microcarcinoma in a girl from an iodine sufficient area. Horm Res Paediatr. 2011;2:309.

32. Campenni A, Ruggeri RM, Saraceno G, Carlotta D, Giovinazzo S, Nania R, et al. Follicular variant of papillary thyroid carcinoma presenting as a toxic nodule in an adolescent girl. Eur J Nucl Med Mol Imaging. 2011;2:S398.

33. Damle N, Gupta S, Kumar P, Mathur S, Bal C. Papillary carcinoma masquerading as clinically toxic adenoma in very young children. J Pediatr Endocrinol Metab. 2011;24(11-12):1051-4.

34. Ducci M, Appetecchia M, Marzetti A. Differentiated carcinoma in autonomously functioning thyroid nodule: case report. Acta Otorhinolaryngol Ital. 1996;16(3):281-5.

35. Mircescu H, Parma J, Huot C, Deal C, Oligny LL, Vassart G, et al. Hyperfunctioning malignant thyroid nodule in an 11-year-old girl: pathologic and molecular studies. J Pediatr. 2000;137(4):585-7.

36. Rees DO, Anthony VA, Jones K, Stephens JW. Follicular variant of papillary thyroid carcinoma: an unusual cause of thyrotoxicosis. BMJ Case Rep. 2015; 06:06.

37. Ruggeri RM, Campenni A, Giovinazzo S, Saraceno G, Vicchio TM, Carlotta D, et al. Follicular variant of papillary thyroid carcinoma presenting as toxic nodule in an adolescent: coexistent polymorphism of the TSHR and Gsalpha genes. Thyroid. 2013;23(2):239-42.

38. Siddiqui AR, Karanauskas $\mathrm{S}$. Hurthle cell-carcinoma in an autonomous thyroid-nodule in an adolescent. Pediatr Radiol. 1995;25(7):568-9.

39. Tfayli HM, Teot LA, Indyk JA, Witchel SF. Papillary thyroid carcinoma in an autonomous hyperfunctioning thyroid nodule: case report and review of the literature. Thyroid. 2010;20(9):1029-32.

40. Abs R, Stevenaert A, Beckers A. Autonomously functioning thyroid nodules in a patient with a thyrotropin-secreting pituitary adenoma: possible causeeffect relationship. Eur J Endocrinol. 1994;131(4):355-8.

41. Appetecchia M, Ducci M. Hyperfunctioning differentiated thyroid carcinoma J Endocrinol Investig. 1998;21(3):189-92.

42. Ardito G, Vincenzoni C, Cirielli C, Guidi ML, Corsello MS, Modugno P, et al. Papillary thyroid carcinoma mimicking an autonomous functioning nodule. Eur J Surg Oncol. 1997;23(6):569.

43. Bajja MY, Benassila FZ, Abada RL, Mahtar M, Chadli A. Mucinous carcinoma of the thyroid: a case report and review of the literature. Ann Endocrinol. 2017;78(1):70-3

44. Bitterman A, Uri O, Levanon A, Baron E, Lefel O, Cohen O. Thyroid carcinoma presenting as a hot nodule. Otolaryngol Head Neck Surg. 2006; 134(5):888-9.

45. Bommireddipalli S, Goel S, Gadiraju R, Paniz-MondolFi A, DePuey EG. Follicular variant of papillary thyroid carcinoma presenting as a toxic nodule by I-123 scintigraphy. Clin Nucl Med. 2010;35(10):770-5.

46. Calimon MAP, Lim-Uy SW. Papillary Thyroid Carcinoma in an Autonomous Hyperfunctioning Thyroid Nodule. Endocr Rev. 2014;35(3).

47. Camacho P, Gordon D, Chiefari E, Yong S, DeJong S, Pitale S, et al. A Phe 486 thyrotropin receptor mutation in an autonomously functioning follicular carcinoma that was causing hyperthyroidism. Thyroid. 2000;10(11): 1009-12.

48. Cirillo RL Jr, Pozderac RV, Caniano DA, Falko JM. Metastatic pure papillary thyroid carcinoma presenting as a toxic hot nodule. Clin Nucl Med. 1998; 23(6):345-9.

49. Clement K, Levy L, Coutris G, Herve JP, Nordlinger B, Duhirel R, et al. Thyroid-cancer revealed by an extinctive hot nodule. Presse Med. 1991; 20(43):2191-3.

50. De Rosa G, Testa A, Maurizi M, Satta MA, Aimoni C, Artuso A, et al. Thyroid carcinoma mimicking a toxic adenoma. Eur J Nucl Med. 1990; 17(3-4):179-84.

51. Einert A, Blattmann $H$, Reinhardt M, Moser E. A combination of UNIFOCAL thyroid autonomy and follicular carcinoma - a CASE-report. Radiologe. 1995; 35(8):531-4.

52. Emmrich $\mathrm{P}$, Gauer J, Mattig H. Unifocal autonomous thyroid nodule and carcinoma. Zentralblatt Fur Chirurgie. 2001;126(9):672-5.

53. Foppiani L, Del Monte P, Marugo A, Arlandini A, Sartini G, Marugo M, et al. Heterogeneous malignancy in toxic thyroid nodules. J Endocrinol Investig. 2005:28(3):294-5. 
54. Fuhrer D, Tannapfel A, Sabri O, Lamesch P, Paschke R. Two somatic TSH receptor mutations in a patient with toxic metastasising follicular thyroid carcinoma and non-functional lung metastases. Endocr Relat Cancer. 2003; 10(4):591-600

55. Fukata S, Tamai H, Matsubayashi S, Nagai K, Hirota Y, Matsuzuka F, et al. Thyroid carcinoma and hot nodule. Eur J Nucl Med. 1987;13(6):313-4.

56. Majima T, Doi K, Komatsu Y, Itoh H, Fukao A, Shigemoto M, et al. Papillary thyroid carcinoma without metastases manifesting as an autonomously functioning thyroid nodule. Endocr J. 2005;52(3):309-16.

57. Nemec J, Zeman V, Nahodil V, Vana S, Zamrazil V, Smejkal V Jr, et al. Metastatic thyroid cancer with severe hyperthyroidism mimicking independent hyperfunctioning thyroid adenoma, showing transition to water-clear-tumour. Endokrinologie. 1980;75(2):197-204.

58. Niepomniszcze $H$, Suarez $H$, Pitoia F, Pignatta A, Danilowicz K, Manavela $\mathrm{M}$, et al. Follicular carcinoma presenting as autonomous functioning thyroid nodule and containing an activating mutation of the TSH receptor (T620I) and a mutation of the Ki-RAS (G12C) genes. Thyroid. 2006;16(5):497-503.

59. Nishida AT, Hirano S, Asato R, Tanaka S, Kitani Y, Honda N, et al. Multifocal hyperfunctioning thyroid carcinoma without metastases. Auris Nasus Larynx. 2008:35(3):432-6.

60. Sandler MP, Fellmeth B, Salhany KE, Patton JA. Thyroid carcinoma masquerading as a solitary benign hyperfunctioning nodule. Clin Nucl Med. 1988;13(6):410-5.

61. Schneider PW, Meier DA, Balon H. A clear cell variant of follicular carcinoma presenting as an autonomously functioning thyroid nodule. Thyroid. 2000; 10(3):269-73.

62. Stahl A, Hess U, Harms J, Zwicknagl M, Langhammer H. Differentiated thyroid carcinoma in a scintigraphically hot nodule: diagnosis and interdisciplinary therapeutical approach. Wien Klin Wochenschr. 2002; 114(10-11):410-4.

63. Wong CP, AuYong TK, Tong CM. Thyrotoxicosis: a rare presenting symptom of Hurthle cell carcinoma of the thyroid. Clin Nucl Med. 2003;28(10):803-6.

64. Schröder S, Marthaler B. Autonomous function and malignancy in thyroid tumours: a critical analysis of data in the literature on the existence of hyperfunctioning follicular and papillary thyroid carcinomas. Pathologe. 1996;17(5):349-57.

65. Pazaitou-Panayiotou K, Perros P, Boudina M, Siardos G, Drimonitis A Patakiouta F, et al. Mortality from thyroid cancer in patients with hyperthyroidism: the Theagenion Cancer hospital experience. Eur J Endocrinol. 2008;159(6):799-803.

66. Francis GL, Waguespack SG, Bauer AJ, Angelos P, Benvenga S, Cerutti JM, et al. Management guidelines for children with thyroid nodules and differentiated thyroid Cancer. Thyroid. 2015;25(7):716-59.

67. Gozu H, Avsar M, Bircan R, Sahin S, Ahiskanali R, Gulluoglu B, et al. Does a Leu 512 Arg thyrotropin receptor mutation cause an autonomously functioning papillary carcinoma? Thyroid. 2004;14(11):975-80.

68. Lado-Abeal J, Celestino R, Bravo SB, Garcia-Rendueles MER, de la Calzada J, Castro I, et al. Identification of a paired box gene 8-peroxisome proliferatoractivated receptor gamma (PAX8-PPAR gamma) rearrangement mosaicism in a patient with an autonomous functioning follicular thyroid carcinoma bearing an activating mutation in the TSH receptor. Endocr Relat Cancer. 2010;17(3):599-610.

69. Russo D, Arturi F, Pontecorvi A, Filetti S. Genetic analysis in fine-needle aspiration of the thyroid: a new tool for the clinic. Trends Endocrinol Metab. 1999;10(7):280-5.

70. Russo D, Tumino S, Arturi F, Vigneri P, Grasso G, Pontecorvi A, et al. Detection of an activating mutation of the thyrotropin receptor in a case of an autonomously hyperfunctioning thyroid insular carcinoma. J Clin Endocrinol Metab. 1997;82(3):735-8.

71. Kent WD, Hall SF, Isotalo PA, Houlden RL, George RL, Groome PA. Increased incidence of differentiated thyroid carcinoma and detection of subclinical disease. CMAJ. 2007;177(11):1357-61.

72. Harach HR, Sanchez SS, Williams ED. Pathology of the autonomously functioning (hot) thyroid nodule. Ann Diagn Pathol. 2002;6(1):10-9.

73. Eszlinger M, Lau L, Ghaznavi S, Symonds C, Chandarana SP, Khalil M, et al. Molecular profiling of thyroid nodule fine-needle aspiration cytology. Nat Rev Endocrinol. 2017;13(7):415-24.

74. Attie JN. The use of radioactive iodine in the evaluation of thvroid nodules. Surgery. 1960:47:611-22.
75. Rojeski MT, Gharib H. Nodular thyroid disease. Evaluation and management. N Engl J Med. 1985;313(7):428-36.

76. Veith FJ, Brooks JR, Grigsby WP, Selenkow HA. The nodular thyroid gland and Cancer. A practical approach to the problem. N Engl J Med. 1964:270:431-6.

77. Hegedus L. Clinical practice. The thyroid nodule. N Engl J Med. 2004;351(17): 1764-71.

78. Tuttle RM, Haddad RI, Ball DW, Byrd D, Dickson P, Duh QY, et al. Thyroid carcinoma, version 2.2014. J Natl Compr Cancer Netw. 2014;12(12):1671-80 quiz 80.

79. Adam B, Orsolya S, Ildiko G. Diagnostic value of TC99M pertechnetate and MIBI scintigraphy in case of thyroid nodes. Nucl Med Rev. 2017;20(2):117.

80. Ahuja S, Ernst H. Hyperthyroidism and thyroid carcinoma. Acta Endocrinol, 1991;124(2):146-51.

81. Als C, Gedeon P, Rosler H, Minder C, Netzer P, Laissue JA. Survival analysis of 19 patients with toxic thyroid carcinoma. J Clin Endocrinol Metab. 2002; 87(9):4122-7.

82. Angusti T, Codegone A, Pellerito R, Favero A. Thyroid cancer prevalence after radioiodine treatment of hyperthyroidism. J Nucl Med. 2000;41(6): 1006-9.

83. Berker D, Isik S, Ozuguz U, Tutuncu YA, Kucukler K, Akbaba G, et al. Prevalence of incidental thyroid cancer and its ultrasonographic features in subcentimeter thyroid nodules of patients with hyperthyroidism. Endocrine. 2011;39(1):13-20.

84. Christensen SB, Bondeson L, Ericsson UB, Lindholm K. Prediction of malignancy in the solitary thyroid nodule by physical examination, thyroid scan, fine-needle biopsy and serum thyroglobulin. A prospective study of 100 surgically treated patients. Acta Chir Scand. 1984;150(6):433-9.

85. Das AB, Alam MN, Haq SA, Ansari MA, Rahman AN, Hasan M, et al. Solitary thyroid nodule: a study of 100 cases. Bangladesh Med Res Counc Bull. 1996; 22(1):12-8.

86. de Luca F, Chaussain JL, Job JC. Hyperfunctioning thyroid nodules in children and adolescents. Acta Paediatr Scand. 1986;75(1):118-23.

87. Gabriele R, Letizia C, Borghese M, De Toma G, Celi M, Izzo L, et al. Thyroid cancer in patients with hyperthyroidism. Horm Res. 2003;60(2):79-83.

88. Giles $Y$, Fatih T, Harika B, Yersu K, Tarik T, Serdar T. The risk factors for malignancy in surgically treated patients for Graves' disease, toxic multinodular goiter, and toxic adenoma. Surgery. 2008;144(6):1028-36

89. Hodax JK, Reinert SE, Quintos JB. Autonomously functioning thyroid nodules in patients <21 years of age: the Rhode Island hospital experience from 2003-2013. Endocr Pract. 2016;22(3):328-37.

90. Kitahara CM, Farkas DKR, Jorgensen JOL, Cronin-Fenton D, Sorensen HT. Benign thyroid diseases and risk of thyroid Cancer: a Nationwide cohort study. J Clin Endocrinol Metab. 2018;23:23.

91. Ly S, Frates MC, Benson CB, Peters HE, Grant FD, Drubach LA, et al. Features and outcome of autonomous thyroid nodules in children: 31 consecutive patients seen at a single center. J Clin Endocrinol Metab. 2016;101(10):3856-62.

92. Miccoli P, Minuto MN, Galleri D, D'Agostino J, Basolo F, Antonangeli L, et al. Incidental thyroid carcinoma in a large series of consecutive patients operated on for benign thyroid disease. ANZ J Surg. 2006;76(3):123-6.

93. Mizukami Y, Michigishi T, Nonomura A, Yokoyama K, Noguchi M, Hashimoto T, et al. Autonomously functioning (hot) nodule of the thyroid gland. A clinical and histopathologic study of 17 cases. Am J Clin Pathol. 1994;101(1):29-35.

94. Rosler H, Wimpfheimer C, Ruchti C, Kinser J, Teuscher J. Hyperthyroidism in patients with thyroid cancer. Nukl Med Isotope Me Biol. 1984;23(6):293-300.

95. Shaikh IA, Muthukumarsamy G, Vidyadharan R, Abraham SJ. High incidence of thyroid cancer in toxic multinodular goiters. Asia-Pac J Clin Oncol. 2007; 3(3):119-24.

96. Smith JJ, Chen X, Schneider DF, Nookala R, Broome JT, Sippel RS, et al. Toxic nodular goiter and Cancer: a compelling case for thyroidectomy. Ann Surg Oncol. 2013;20(4):1336-40.

97. Smith M, McHenry C, Jarosz H, Lawrence AM, Paloyan E. Carcinoma of the thyroid in patients with autonomous nodules. Am Surg. 1988;54(7):448-9.

98. Zanella E, Rulli F, Muzi M, Sianesi M, Danese D, Sciacchitano S, et al. Prevalence of thyroid cancer in hyperthyroid patients treated by surgery. World J Surg. 1998;22(5):473-8.

\section{Publisher's Note}

Springer Nature remains neutral with regard to jurisdictional claims in published maps and institutional affiliations. 